Proceedings of the $51^{\text {st }}$ Hawaii International Conference on System Sciences | 2018

\title{
The Future of Academic Research in Information Systems Economics: From Information Systems and Strategy to Innovative Business Models, Social Impacts, Public Policy, Regulation, and the Law
}

\author{
Eric K. Clemons \\ The Wharton School \\ clemons@upenn.edu
}

\begin{abstract}
The academic research community is going to augment its research and teaching focus once again, comparable to the change in the 1980s when studying management of information was augmented with studying the impact of information on management. Just as information economics became newly significant for research and teaching in business school's $M B A$ programs, there will be an increasing focus on the impact of information on society and social welfare. The study of strategy will be augmented by the strategy of social policy, regulation, and the law. This will allow us to exploit our competitive advantage over researchers in large technology firms, which enjoy greater access to data, computing, and analytical staff. This will also make us more valuable to our students and to society.
\end{abstract}

\section{Introduction}

We suggest that the future of academic information systems research, and especially research as it will be conducted at major business schools, is going to be transformed over the coming decade. Thirty years ago business school MIS research augmented its traditional study of database management and other emerging areas of technology, and its study of software development, software implementation and adoption, and technology management, and began to include work at the intersection of information economics and information-based strategy. As firms like Google, Facebook, Amazon, Apple, and others make breakthrough advances in information-based strategy, academic business school researchers in information-based strategy may find it harder to compete directly with them. We believe that the emerging focus of business school research in information systems economics is going to be at the intersection of disciplines like information-based business models, the societal impacts of business and technological innovation, social welfare, regulatory policy, and the law. In addition to allowing information systems economics faculty to work in an area where they can exploit a competitive advantage, this work will be of great value to our students as they assume leadership positions, to corporations that need to understand the future of regulation in order to plan, and to society more broadly.

We are advocating an augmentation of research focus, methodology, and reference disciplines in the MIS research community, one as profound as the URI: http:/hdi.handle.net/10125/50541

ISBN: 978-0-9981331-1-9

(CC BY-NC-ND 4.0)

\author{
Josh Wilson \\ University of California at Berkeley \\ wilsonjs@berkeley.edu
}

transformation that occurred in the late 1980s with a shift from managing technology to technology's impact on management. We are proposing that the focus of MIS research in information economics needs to shift away from the impact of innovative uses of information on the firm, and now needs to focus more on the impact of innovative uses of information on society. Research in information economics will need to broaden beyond economics, economic modeling, and econometric analysis of performance that focus on information technology's implications for business strategy, and will need to address critical problems in social welfare, social policy, regulation, and the law.

McFarlan proposed that we study how information and information systems changed management, changed strategy, and changed business [43]. His work at this time advocated that the teaching of Management Information Systems needed to be transformed from the Management of Information Systems and the management of information technology hardware and software, to the impact of Information Systems on Management and the management of organizations in the presence of information. He proposed that academic research would need to shift in order to enable this new focus in teaching.

The field rapidly responded and rapidly embraced the transformation. A quick review of the actions that followed quickly thereafter will be helpful. In 1986 Yannis Bakos and Michael Treacy published their work on the new reference disciplines underlying academic research in management information systems [2]. The response broadened when Clemons launched his mini-track on Information, Telecommunications, and Strategy at HICSS in 1988 (See, for example, [15, 16] and when the Journal of Management Information Systems began to publish a special issue on the best research from that mini-track in 1989 (see, for example $[16,17])$. The transformation of the field and the acceptance of its new focus became mainstream when Yannis Bakos and Chris Kemerer held the first Workshop on Information Systems and Economics in Cambridge in 1989 (See conference website [http://misrc.umn.edu/wise/previous_years2016.html].

Bakos and Treacy [2] began to formalize the references disciplines that underlie online strategy, going beyond McFarlan's embracing of Porter to solidify the links with economics and information economics. Clemons searched for the intersection between economic theory and empirical observation, and his HICSS colleagues began publishing refereed case 
studies that explored theory $[15,16]$, modeling that extended and formalized theory [17, 20,21], ethnographic and anthropological studies [38, 39], and more quantitative econometric and empirical studies that solidified our belief in theory [19,34]. Bakos and Kemerer's WISE succeeded in bringing in a broad community of faculty interested in economic modeling of information-based strategies and online business models.

We suggest that for a variety of reasons research in information systems economics will need to address the future social and societal impacts of the deployment of online technology and online business models. This research needs to address understanding the distribution of future benefits and the potential for future harm. This is not divorced from the MIS community's current focus on information economics and strategy, but rather is deeply linked to it. We now have a far better idea of how firms can exploit information and online business models for strategic advantage, and when that advantage may indeed be unassailable and beyond competitive pressures. We do not yet know how to harness those strategies to maximize social welfare or how to distribute social welfare in a way that is in some sense equitable.

The advantages to our academic community from this shift of focus are clear. In the 1980s we claimed for ourselves and our Ph.D. students an area that was of great importance to business and to MBA students, and that was not yet fully embraced by computer science, business strategy, or economics. Once again, we have the opportunity to claim an area that is of great importance, and that has not yet been fully embraced by computer science, regulatory economists, or the law. This work will be important to business school graduates, of course, and to society. It will provide decades of research opportunities, increase enrollments for our course, and provide great value to our school's graduates, to business, and to society. It will exploit an area where MIS faculty have an advantage over computer science researchers on the one hand and economists on the other, in that we combine both an intuitive understand of the role of information and an equally intuitive understanding of information economics. Additionally, the high degree of relevance, even urgency, of the research will provide greater visibility for the profession and its professional societies.

The work initially generated by this study will need to address the following questions:

- How might technology, information access, and information-based businesses affect society? Which segments of society might benefit disproportionately and which segments might be harmed?

- What social policies might minimize harm and which social policies might be preferred?

- What regulatory policies might be considered to implement those social policies?

- As importantly, it will seek to address when regulation might be unnecessary, because the necessary is- sues will be addressed by society and by informed consumers.

The work is interdisciplinary, and the underlying disciplines include information systems economics, social impact, law and regulatory policy, and anthropology and ethnography. Its methodology will be similarly interdisciplinary, requiring economic modeling, computer simulation, focus groups and surveys, scenario analysis, big data analytics, history of science and technology, legal history, and regulatory policy.

\section{Social Context}

As we know, modern information technology is dramatically changing business, economics, and society. In aggregate and on average, these changes are beneficial. However, the benefits of technology, and of each of its applications, are distributed unevenly. As with any disruption, there are be winners and losers.

As with previous technologies associated with mass production of textiles and heavy industry, there has been both the great creation of wealth, and the creation of unemployed or under-employed workers. Recent technological innovations have already exacerbated income inequality [46], in part due to the winner-take-all [30] aspects of many innovative apps and online business models $[6,31]$. There may be additional unforeseen impacts, where wealth disparity and income inequality are exacerbated further, and although society benefits as a whole, some sectors of the labor market and some segments of the economy are significantly worse off, perhaps for extended periods of time.

There may be unforeseen risks associated with the winner take all nature of some businesses, due to first mover effects reinforced by economies of scale or network effects, where the first established player may have the power to eliminate competition and stifle innovation.

There may be unforeseen risks associated with firms that gain dominance in one industry or one market segment, and then use that power to dominate other areas, again potentially limiting competition and stifling innovation $[8,10]$.

There may even be areas in which many users gain, but other participants are harmed, with harm that potentially outweighs the gains. Uber benefits riders who can afford surge pricing, but harms the regulated taxi industry; perhaps the solution is as simple as regulating Uber or unregulating taxis. Airbnb benefits both those with space to rent on a short-term basis and those who want to obtain short-term housing, but its implications for the broader communities around those renting out their space are as yet unclear $[5,40]$.

At present we can frame far more questions than we can answer.

- How would we know how to design our policies? More specifically, how would we define the greatest good that could be produced by a transformative innovation and how would we know ffaidg 
been achieved?

- How would we regulate these emerging businesses to achieve the greatest good? How would we measure policy improvement? What is the need for policy improvement? What regulations will yield improvement?

- Wow would we regulate to ensure that while trying to help we did not increase harm or limit the benefits from innovation? This could happen through premature or inappropriate regulation, that reduced competition or stifled innovation?

\section{Methodological Framework}

This research will need to draws its theoretical foundations from the history of technological innovation, the history of business strategy, information economics, and regulatory economics.

Methodologically, it will embrace the broadest set of disciplines available to MIS researchers working in information systems economics. It will use ethnographic observation, surveys, focus groups, scenario analysis, economic modeling, and computer simulation to develop and test hypotheses. Each of these is necessary, for different reasons, allowing for strongly complementary interactions among them.

Ethnographic observation, surveys, and focus groups are necessary in order to understand what members of society know, what they believe, and how they will act to changes. This is essential in designing appropriate policy. It is now clear that public education is not sufficient to persuade young adults not to smoke, or not to drink before driving. The policy banning sale of alcohol and tobacco to young adults would not be necessary if young adults "selfregulated" their consumption of these products. Which online behaviors will be self-regulating? How would we know? What sort of abuses by powerful software firms will be rectified by increased transparency and by public outrage and market response, and which will not? Most importantly, how would we know? How would we perform research in this area in order to determine when transparency and informing the public is sufficient, and when additional interventions might be required? Although there have been a few papers on reasoning from small samples or the use of ethnographic observation, this has not been a core discipline in MIS research information systems economics and strategy [3, 24, 36, 37]

Scenario Analysis is a form of structured exploration, used to examine the wide range of actions possible in uncertain situations, and the wide range of outcomes that might be produced [49, 53, 54].

Economic modeling is the most common mechanism for judging the impact of alternative regulatory policies. It can continue to be used any time comparative statics are appropriate and equilibrium analysis is possible. Since it is the principal focus of much of the MIS strategy research community, and has been a principal focus of WISE and HICSS as noted above, and of the information systems economics and strategy publications of ISR, JMIS, and Management Science, no further references are required here.

Computer simulation is used when the complexity of economic problems is so complex, or when dynamic behavior and trajectories over time are needed, since these make more traditional comparative statics and equilibrium analysis less appropriate. MIT's Sloan School pioneered the use of Industrial Dynamics simulation as a tool for management planning and analysis [29, 51]. A previous HICSS paper presents an early use of computer simulation to explore the regulatory policy implications of competition between complex online platforms [18].

\section{Why should we care about these changes?}

What, if anything, is new about competition online? Clearly, the composition of the Fortune 50 has changed dramatically over the past ten years, and many of the largest companies today by market capitalization do not produce any physical products, do not sell anything directly to consumers, and have no competition of any kind, anywhere in the world. Why should we care about how large these companies got, or about how fast they got this large? Why should we care that they introduced new business models, with unanticipated social consequences? Why should we anticipate any problems at all?

Free Services Subsidized Through Advertising: Many online businesses have business models that we have never seen before. Some companies do not charge their end users anything for services, and have found a way to monetize targeted advertising based on private and personal data extracted from users' accounts. Others have developed spectacularly profitable platform services, and have used the profits from these services to subsidize additional businesses; with subsidies, these businesses operate at price points that no independent competitor can match. And are these business models fundamentally different from prior business models? Why should free services, or services subsidized by earnings on other services, create problems?

First Mover Effects and Positive Externalities: We've seen economies of scale before, and we've seen network effects before. Why should first mover effects, defended by economies of scale, be a greater threat to competition now than previously, and why should it require any change in competition law now? Think about the dominance of Windows after more than three decades of progress in software and in technology generally. Why should first mover effects, defended by the value of large networks of users, be a greater threat to competition now, and why should it require any change in competition law now? Think about what it would take to displace Facebook, which has the largest user base of any social network in the world.

Combining Positive Externalities and Addzerz34 
tising: Now combine free services subsidized through advertising combined with network effects. Again, consider Facebook, which is the largest social network in the world and which already appears to be free to its users. How is this different from earlier subsidized television and radio networks? How could a competitor to Facebook emerge? Why would a user join any other social network, since it would start off much smaller and thus less valuable, and its price could not be lower than free?

Targeted Advertising: Does targeted advertising create problems that traditional advertising does not $[9,48]$ ? Why should targeted advertising be any different from blanket shotgun broadcast advertising? Does it matter if ads target children? Does it matter if ads appear to come from friends? Does it matter if social networks pay members to authorize the network to send ads to these members' friends, where the content is actually provided by the network and optimized to produce the strongest possible response among recipients?

Bundling and Platform Envelopment. Why should value-adding strategies based on bundling as many services as possible be any different from oneshop stopping at a really good super-market, megamarket, or hypermarché? Yes, platform operators have enormous power to determine what is placed on their devices and where it is place $[8,10]$. Google's Mobile Services Distribution Agreement allows it to determine which apps must be placed on its manufacturers' devices and where these apps must be placed, and which apps cannot be placed on their devices. Yes, this gives Google the ability to promote its own offerings and the ability to crush competitors. But, again, how is this different from the power of giant retailers such as Wal-Mart or Tesco?

\section{Is there a need for policy and for a regulatory response?}

Why should we believe that a coherent new social policy is going to be required, and why should we believe that we have not had sufficient time to develop such policy? And why do we believe that there are going to be unique regulatory problems, requiring unique solutions and why should we believe that we have not had sufficient time to develop appropriate solutions?

There are historical precedents for social disruption and social problems in the presence of extreme change, even in the absence of such extreme speed. And with this speed, the prospects for regulation by trial and error are not promising. With AT\&T it took decades of trial and error to design the right regulatory regime $[42,55]$.

Initially it was thought that AT\&T could be regulated as a form of interstate commerce. The ICC was effective in regulating rail traffic, but was not suited for regulating telecommunications. Rail networks were different, with different sources of power, differ- ent sources of competition, and different issues in interconnectivity and interoperability. Consequently, the ICC was not the right regulatory framework for telecoms. The Sherman Antitrust Act worked to ensure competition in heaving industries like steel, coal, oil refining and distribution, and other industries where there was no compelling need for interoperability across company boundaries, but was not the right model for telecoms. The nation's ability to obtain the products of heavy industry were not limited by dividing companies to reduce monopoly power; with the technologies of the late 1800 s and early 1900 s breaking up AT\&T would have limited the ability of telephone users to call each other. The Kingsbury Commitment worked well for almost two decades when AT\&T was solely in the wire-line communications industries. However, when its domination of long lines traffic allowed AT\&T to threaten vertical integration and threaten to dominate the emerging broadcast radio network industry, then a new regulatory framework needed to be considered.

The ICC, the Sherman Act, and the Kingsbury Commitment all proved less than entirely effective in regulating AT\&T and emerging radio and television network broadcasting. Not all large firms are the same. Not all forms of interstate commerce are the same. Not all sources of first mover advantage are the same. Standardization easily created interoperability in rail traffic, but not in telecoms. It was impossible for railroads to vertically integrate into meat packing and gain an advantage over other meat packers, but easy for AT\&T to vertically integrate into broadcast radio and cripple competition. Creation of the FCC was the result of decades of trial and error, before an appropriate regulatory structure was understood.

Even one or two examples should be sufficient to illustrate how ill-prepared we may be for some the changes that might emerge from today's new technologies and new business models.

\subsection{Real-Time Pricing, Reallocation of Scarce Re- sources, and Society's Perceptions of Fairness}

Uber has introduced a form of price efficiency that has led to allocative efficiency. With surge pricing, those of us who most want cars are allocated them because we are willing to pay more to get a car quickly; likewise, with surge pricing drivers who might not be willing to drive for lower payments are tempted to join the pool of drivers at peak times. With Uber, we all have an opportunity to pay what we are willing to pay for transportation. If we are not in a hurry, a shared Uber $X$ is the cheapest way to travel. If we want a car immediately, during a snowstorm or during normal rush hour, we can get an Uber Black car quickly, even when taxis are not available; however, we will pay significantly higher prices. Economists love the efficiency this creates, but society may want to ask when this form of spot market differential pricing is not acceptable. Is it ok for hotel roomPtoge 5235 
charge different prices at different times of year, or during special events, or even based on whether the guest is a business traveler or a vacation traveler? Most of us would agree that it is. Is it acceptable for scarce organ transplants to be allocated to the highest bidder? Most of society would agree that it is not. Are there forms of price efficiency that are less clear cut, like allowing an airline to charge fees based on how desperately we need to travel, or like allowing insurance companies to charge prices for coverage that are closely tied to data mining, privacy violations, and deep profiling of individuals based on financial risk, health, or other factors? What if some of these factors are closely correlated with race? As a society we are less clear about the fairness of some forms of differential pricing than we are about others. We have not had time as a society to develop an informed consensus on how we feel about delegating the authority to collect that much information by for-profit firms, for the use by a host of other for-profit firms, when the information can be used to charge some citizens very different prices from those paid by others. However, if these practices can be performed without public visibility, and if they confer competitive advantage on the firms that do them best, market forces alone are unlikely to implement preferred public policies.

\subsection{Business Models for the Sharing Economy, Externalities, and Society's View of Fairness}

Without platforms such as Airbnb the sharing economy would be impossible. These platforms are new enough that society has not had sufficient experience to balance costs and benefits, or to balance risks and rewards. Airbnb provides clear benefits both to people who want to earn a little extra money by offering their homes as accommodations to renters, and to short term renters who want to obtain housing but don't want to stay in traditional hotels. And yet, Singapore is concerned that short term rentals "off the grid" might be very convenient for terrorists and almost impossible to trace. Other cities are concerned that long-term tenants might be forced out of their apartments and entire regions of the city might become de facto hotels, reducing the available residential housing market while providing unfair competition to existing hotels $[7,22,23]$. Other cities are concerned that mixing short term renters with long term residents might significantly alter the character of their cities. How should these concerns be balanced? What obligation does Airbnb have to measure the impact of these externalities on the quality of life in the markets they serve? What obligations if any does Airbnb have to address potential negative impacts? Again, as a society we have not had time to develop a policy on the externalities of these sharing economy platforms. However, it has been known for centuries that markets alone do not address the problems created by externalities; by definition, they are outside the scope of market forces. Once again, if the practices that result in harm through externalities are not mitigated or controlled by markets, then market forces alone are unlikely to implement preferred public policies.

\section{Why do we believe that some regulatory action may be required?}

We believe that although regulation of technology has evolved significantly over the past century, it is still heavily focused on the problems created by massive industrialization of the late $1880 \mathrm{~s}$. Regulation of giant manufacturers and other forms of heavy industry may provide little guidance for the regulation of today's online businesses. Regulation of externalities from pollution may have little to tell us about the externalities of the sharing economy. Regulation of meat packing and even of tobacco may have little to tell us about the dangers of online services. Search warrants and legal protection of even traditional electronic communications may not be adequate for data stored in the cloud [13].

For a variety of reasons, we believe that many of the issues raised in section 4 do indeed have the potential to create significant harm. Moreover, we believe that these problems may not be fully addressed by existing laws and regulations. First, some platforms have created new forms of externalities, benefiting participants in the platforms but harming others in the community who have no interactions with the platforms and indeed might not benefit from interacting with the platforms. We have had decades to learn to deal with some forms of externalities, like physical pollution caused by agriculture or heavy industry; often, despite decades of experience our regulations are still unclear or ineffective. New platforms, with externalities that are difficult to detect, assess, or measure accurately, are certain to produce new regulatory conflicts. Additionally, as we have seen, there are new tradeoffs among price efficiency, allocative efficiency, and a real but poorly understood and illdefined sense of social fairness.

As importantly, we believe that in the absence of laws and regulations markets alone will not solve these newly emerging problems. This is true even if some countries impose regulations, while others do not [11].

\subsection{New externalities may create new challenges}

Historically, altruism has not been sufficient to correct all problems caused by externalities. Consider the harm caused down-wind by the widespread burning of Indonesian forests. Closer to home, consider the harm caused by toxic dumping or by the burning of high sulfur coal. When the economic benefits of one actor are great enough, harm to other parties are systematically discounted or ignored. Indeed, this has been the origin of zoning policies and environmental laws and regulations around the world. The markets may "endorse" things that are good for buyers and sethags, b0.86 
not for the broader public. Economists have known for centuries that markets do not fully encompass the impacts of externalities and do not price externalities into the costs of goods and services. This is one of the principal reasons why we have regulations. Indeed, it is even possible that the markets may endorse things that are not even good for the buyers, but without their knowing it. The widespread adoption of cigarettes, for example, and the need to regulate cigarette advertising, alcohol advertising, and the sale of tobacco and alcohol to minors are all examples where society has decided that the costs of uninformed decisions by some are too high. Society has decided that the costs are too high, and even the individual decision makers may need to be protected from the downsides of their own decisions. This is a second reason for regulations. Finally, we may need more regulations when the natural advantages of a first mover are so great that they may make competition impossible [14].

\subsection{MP3PP Power, Including Monopoly Pricing and Cross Subsidies and Vertical Integration:}

MP3PPs do not look like monopolies, and yet they often enjoy monopoly power. MP3PPs are able to use their monopoly profits to provide numerous free goods and services, which initially appear to benefit consumers. However, since these destroy even the possibility of competition, they may ultimately lead to future harm. And yet both are outside the historical scope of competition law, in the US and abroad [8, 10, $14,18]$.

\subsection{Systematic Privacy Violations for Differential Pricing and for Targeted Ads}

Nothing in existing regulation appears to deal with the delayed and hidden harm from privacy violations. Our online activities allow service providers to create a detailed and accurate profile of our preferences, our habits, our desires, our willingness to pay for goods and services, the risks we face, and the costs to serve us. The current benefits from our activities are clear now [48]. The future downsides are both uncertain and not visible to us now. Nothing in existing regulation appears to address the reallocation of resources due to the potential of market pricing of everything. As a society, we have discussed the role of differential pricing in markets like air travel and credit card fees, which do appear not to be problematic. We do not know how we would react to the instant individualized market pricing of everything from transportation to medical care.

Historically, people have not been able to make fully informed decisions in their own self-interest, when the benefits of an action are immediate, certain, and visible, but the harm is delayed, uncertain, and not yet visible. Everyone knows that cigarettes are harmful, and many people know that obesity is associated with cardiovascular disease, higher risk of stroke, and type 2 (non-genetic) diabetes. And yet, people smoke and consume vast amounts of sugar-laden soft drinks and fatty fried snacks.

There is at present ample evidence that people are unaware of the long-term costs associated with the immediate benefits from using online software that employs deep data mining, employs in-depth profiling, and uses this information for targeted marketing. There is ample evidence that they are either unaware of the costs or systematically underestimate the costs.

As a society we have decided to limit the sale of cigarettes to minors, to make cigarette smoking more difficult and more expensive for adults, and to take assorted other regulatory actions to help people improve their own health. Do we need to consider protecting the online privacy of minors? Do we need to consider the online privacy of everyone, to the extent that data mining and deep profiling may affect the prices we all pay for goods and services in the future?

\subsection{Search Bias and the Manipulation of Public Opinion}

Nothing in existing regulation appears to address the problems of intentional search bias and the potential for manipulation of public opinion. Recent studies have demonstrated the search engine bias can be used to manipulate public opinion before elections and referenda $[25,26]$. There is no Federal Search Commission to ensure fairness, much the way the Federal Communications used to ensure fairness when there was a small number of TV stations and bias could indeed affect the electorate's access to information. With search now far more concentrated than media, and with search bias much harder to detect than media bias, is it necessary to enforce some form of fairness in search? How could that be defined or implemented $[4]$ ?

\subsection{Fake News and the Future of Democracies}

Nothing in existing regulation appears to address the problems associated with the ease of disseminating fake news. First Amendment rights allow all of us to say whatever we want, subject to a few restrictions like not advocating violent overthrow of the elected government. But fake news on social media can reach millions of viewers very quickly; fake news is inherently different from one-on-one private speech, or even speaking on a soap box on Speakers Corner in Hyde Park, London. Anecdotal evidence suggests that by the end of the 2016 elections in November, fake news stories were being shared online with frequency equaling or even exceeding that of fact-checked mainstream media. Moreover, a fake news story may be shared hundreds of thousands or millions of times, while its retraction or refutation may be shared only thousands of times. The impact of fake news on the Brexit Referendum is becoming clear $[32,50]$. The impact of fake news on the American election of 2016 may never be entirely clear $[27,45]$. Moreover, fake news is emerging as a potential issue in upcorraigg 5237 
elections throughout the EU, and it is becoming clear that increasingly citizens choose what to believe from numerous alternatives on offer online, and are less and less influenced by facts [35]. Websites like Facebook are seen as increasingly culpable [28], and are attempting to police themselves [44], but this is proving difficult to accomplish.

If a regulatory response is required for any of these issues, it may be essential that the response be rapid. Unprecedented speed of analysis, debate, and response may be required. New companies and new industries are emerging at unprecedented speeds. If regulatory decisions are required, delays of decades may result in truly unacceptable individual and social costs, and may result in irreparable harm. It may also result in the entrenchment of special interests that it would be almost impossible to displace.

It is however possible that no action is required. There may not actually be any problems that require regulatory intervention. First and foremost, no regulatory action would be required if there is no harm that requires redressing. This requires modeling and the sort of analysis described above. Moreover, no regulatory action would be required if whatever harm might occur were certain to be self-rectifying. That is, no regulatory intervention would be required if it were certain that any problems that might arise in a specific area or through a specific business model could be corrected by normal market forces. This requires the sort of methodological approaches described in the following section.

\section{Methodologies - How would we know if the market will self-correct all abuses?}

If normal market forces will be sufficient to correct any negative impacts from emerging technologies and new business models, this would render regulation superfluous. Academic research should focus on the following questions, among others that will emerge as the community's research progresses.

\subsection{How will society handle fairness or perceived changes in fairness resulting from new forms of price efficiency and price discrimination?}

Market efficiency has benefits of course; for example, in insurance, low risk individuals are charged less, increasing the likelihood that they purchase insurance. Since low risk individuals still have some risk, properly priced insurance is beneficial to them. Market efficiency also produces harm. High risk individuals are charged more, and may be unable to afford coverage. Efficient pricing in medical insurance is becoming even more pressing. Ever increasing levels of information endowment will allow an increasing number of service providers to implement efficient pricing, basing prices on customers' individual willingness to pay for services, need for those services, cost to provide those services, or other factors that affect expected profitability. When and where will this become is- sues of social concern, and when and where will this require well-formulated social policy and regulatory responses? The raging debates over health care in the US today are proof that our society has not yet figured out how to deal with informed markets and the resulting price efficiency that results. What are other areas where price efficiency and price discrimination will become significant social concerns? We have learned to accept price discrimination and price efficiency in air travel and in financial services. Where else will price discrimination emerge? How will society respond? How should society respond? These questions remain important and they remain unanswered.

\subsection{How will society handle fairness or perceived changes in fairness resulting from new forms of price efficiency and allocative efficiency?}

Most of us have come to accept that business travelers are charged more for flights, and that they are more likely to receive upgrades when they fly and to receive room upgrades when they check into their hotels. Most of us are coming to accept that those of us who really want to travel around town use Uber despite surge pricing, book limousines for their trips in advance, or even book a car and a driver for the day, if we can afford it. And yet our acceptance of surge pricing seems to be at best conditional on their being no acute need for it! Consider the recent international outrage when Uber's surge pricing was automatically invoked in response to an urgent need for cars to leave the area of London Bridge after suicide attacks involving a van mowing down pedestrians $[1,33,52]$. How would we feel if differential pricing allowed food delivery services to charge different prices depending upon how hungry they thought we were, or if airlines began to charge differential prices depending on how urgently we needed to travel?

\subsection{How will society handle the near monopoly power that accrues to operators of online gateways and mandatory participation third party payer systems?}

Online retailers like Amazon can develop market share and reputation beyond that of any individual traditional retailer. Online agencies like hotels.com can develop market share and reputation greater than any traditional competitor. Apple has been found guilty of abusing market power in electronic books distribution [47]. Most anti-monopoly law today deals with controlling the power of giant physical manufacturers and transportation companies; that is, it deals with the industries that dominated the late $19^{\text {th }}$ and mid $20^{\text {th }}$ centuries. Do we need to update antimonopoly law to deal with the giant online retailers that are emerging in the early $21^{\text {st }}$ centuries? We had originally expected online entry to be so easy that no dominant powers would emerge, but this does not appear to be the case. Does the power of an Amazon, or an Orbitz, or the Apple App Store, benefitPorgaaø8 
consumers? If indeed regulation is necessary, do we need to harmonize regulation across the major economies? Does regulation in North America, the EU, China, Japan, and Korea need to be coordinated, or should each nation develop its own policy?

Similarly, online gateways like Google operate as if they were parallel monopolies. Most users singlehome; that is, most buyers do not search for their purchases on two or more search engines. As a result, sellers are required to participate in most or even all search engines in order to ensure that they are found by all buyers. Choice may indeed be just a click away for buyers, but as long as buyers still search with $e i$ ther Google or Bing, sellers must be present on both Google and Bing. That gives both Google and Bing monopoly market share over their own users, and thus gives both Google and Bing extraordinary pricing power in the sale of keywords.

\subsection{How will society respond to platform envelop- ment, when firms use their profits from domi- nant platforms to create new monopolies?}

How will society respond when firms use their power over gateways or the profits from MP3PP system to provide cross subsidies, develop a suite of applications, and engage in platform envelopment strategies? Will these platform envelopment strategies be deemed anti-competitive, and the abusive use of nearmonopoly power, as Microsoft's expansion beyond Windows and its Office Suite were? Will they be given tacit approval even in the case of greater power, as has occurred to date with dominant search engine providers in most locations around the world?

We don't know, and we need do know.

\subsection{And how would we know what response or responses are appropriate?}

How would we know if the market could correct problems directly affecting users? There is a range of research methodologies that would be appropriate for an agenda as broad as ours. We address each of the issues we raised previously and describe the methodologies that would be appropriate. Several research methodologies will certainly need to be combined.

We will need to work with legal scholars and economic historians to understand the social and economic problems that technology has engendered in the past and how legal codes and regulatory environments where shaped to address them.

We will need economic modeling, including dynamic economic and behavioral simulations, to understand the complexity of competitive behavior and of consumer behavior under a wide range of conditions. How will firms compete under various conditions? What will market structure emerge under each - monopoly, duopoly, or effective competition? How will these be altered by consumer awareness of the behavior of firms? Under what conditions and regulatory regimes can markets properly address.
We will need anthropological insights, ethnographic observation, and surveys to determine the extent to which transparency and consumer awareness can address problems. For example, surveys might tell us if consumers are aware of externalities and aware of the extent to which their actions harm others or themselves. Additionally, surveys might tell us that consumers would care, if they knew the harm that their actions caused. It would appear that consumers are aware of the problems caused by smoking, texting while driving, or the excess consumption of sugars and fatty foods; it is also clear from public health problems and traffic fatalities that awareness alone has not eliminated these problems. What lessons, if any, can we learn to guide the policy and regulations in the domain of technology and society?

Finally, we need to ask how society can address all of the complex issues and the interactions among them, and whether it can determine an appropriate regulatory regime quickly enough to prevent harm to consumers and to protect competition. That is, will it decide before firms become so dominant, and so diversified, that regulatory responses are far more complex than they would be if we acted now, before harm occurred and before newly dominant players were firmly entrenched globally.

\section{In Conclusion}

Our research community in information systems economics now faces a great challenge. Much of the work that we now do at the intersection of modeling and information-based strategy is also being done at the innovative firms that have implemented the most aggressive information-based strategies. When compared to the resources available to academic researchers, these firms have virtually unlimited resources and virtually unlimited access both to superbly trained personnel and to the information that their firms generate and need to study. We will be surpassed.

The broader MIS community has faced similar challenges before, when corporate research in the development and modeling of database management outran academic research in the area. Database development organizations like IBM and Oracle had unlimited resources for modeling database management systems, constructing them, and studying their actual performance. We persevered as a community and found new areas for our research, including a focus on implementation, adoption, and technology management and on information-based strategy.

Our community will persevere again.

\section{References}

[1] Agnihotri, A. "Uber's Surge Pricing Tactic During London Bridge Terror Attack Ignites Social Media Outrage", International Business Times, June 5, 2017, http://www.ibtimes.com/ubers-surge-pricingtactic-during-london-bridge-terror-attack-ignitessocial-media-2547799.

Page 5239 
[2] Bakos, J. Y. and Treacy, M. E. "Information Technology and Corporate Strategy: A Research Perspective", MIS Quarterly, Vol. 10, No. 2 (1986), pp. 107-119.

[3] Benbasat, I., Goldstein, D. K., and Mead, M. "The Case Research Strategy in Studies of Information Systems," MIS Quarterly, Vol. 11, No. 3, (1987), pp. 369-386.

[4] Bracha, O. and Pasquale, F. "Federal Search Commission - Access, Fairness, and Accountability in the Law of Search", Cornell L. Rev. Vol. 93, No. 6, (2008), pp. 1149-1209, http://scholarship.law.cornell.edu/clr/vo193/iss6/11.

[5] Brescia, R. H. "Regulating the Sharing Economy: New and Old Insights into an Oversight Regime for the Peer-to-Peer Economy" Nebraska Law Review, Vol. 95, No. 1, (2016), p. 87.

[6] Brynjolfsson, E. and McAfee, A. The Second Machine Age: Work, Progress, and Prosperity in a Time of Brilliant Technologies, W. W. Norton \& Company (2016), pp. 336.

[7] Clarke, K. "Does Airbnb Enable Racism?", The New York Times, 23 August 2016, https://www.nytimes.com/2016/08/23/opinion/howairbnb-can-fight-racialdiscrimination.html? $\mathrm{mcubz}=2$.

[8] Clemons, E. K. "The Real and Inevitable Harm From Vertical Integration of Search Engine Providers Into Sales and Distribution", Huffington Post, 20 April 2011, http://www.huffingtonpost.com/eric-kclemons/the-department-of-justice b 851079.html.

[9] Clemons, E. K. "Online Profiling and Invasion of Privacy: The Myth of Anonymization", Huffington Post, February 20, 2013, http://www.huffingtonpost.com/eric-kclemons/internet-targeted-ads b 2712586.html.

[10] Clemons, E. K. "The EU Files Complaints Against Google, and It's About Time!", Huffington Post, April 15, 2015, http://www.huffingtonpost.com/erick-clemons/the-eu-files-complaints-againstgoogle b 7069780. html.

[11] Clemons, E. K. "Selbstschutz ist nicht gleich Protektionismus (Self-protection is not Protectionism)", Huffington Post, November 11, 2015, http://www.huffingtonpost.de/eric-k-clemons/eudatenschutz-rechtswidrigeunternehmenspraktiken_b_8490876.html.

[12] Clemons, E. K. "Regulating Online Platforms: Where, Not Whether, to Draw the Line: A Position Paper in Prepared in Advance of the Platform Strategy Research Symposium July 14, 2016", Huffington Post, July 01, 2016, http://www.huffingtonpost.com/eric-kclemons/regulating-onlineplatfor_b 10751960.html.

[13] Clemons, E. K. “The Federal Government's Attempt to Force Microsoft to Violate Irish Territoriality 'It's the wrong time, and the wrong place; Though your case is charming, it's the wrong case'", Proceedings, $50^{\text {th }}$ International Conference on System Sciences, Waikoloa, Hawaii, (2017).

[14] Clemons, E. K, and Madhani, N. "Regulation of
Digital Businesses with Natural Monopolies Or Third Party Payment Business Models: Antitrust Lessons from the Analysis of Google," Journal of Management Information Systems, Vol. 27 No. 3, (2010), pp. 43-80.

[15] Clemons, E. K., and Row, M. C. "The Merrill Lynch Cash Management Account Financial Service: A Case Study in Strategic Information Systems", Proceedings, 21st Hawaii International Conference on System Sciences, (1988), pp. 131-140.

[16] Clemons, E. K., and Row, M. C. "McKesson Drug Company: A Case Study of Economost--A Strategic Information System", Journal of Management Information Systems, Vol. 5, No. 1, (1988), pp. 36-50

[17] Clemons, E. K. Row, M. C., and Reddi, S. P. "The Impact of Information Technology on the Organization of Economic Activity: The 'Move to the Middle' Hypothesis'”, Journal of Management Information Systems, Vol. 10, No. 2, (1993), pp. 9-35.

[18] Clemons, E. K. and Wilson, J. "Modeling Competition in Mandatory Participation Third Party Payer Business Models: The Complex Case of Sponsored Search", Proceedings, $49^{\text {th }}$ International Conference on System Sciences, Wailea, Hawaii, (2016).

[19] Dedrick, J., Xu, S. and Zhu, K. "How Does Information Technology Shape Supply Chain Structure? Evidence on the Number of Suppliers." Journal of Management Information Systems, Vol. 25, No. 2, (2008), p.41-72.

[20] Dewan, R. M., Jing, B., and Seidmann, A. “Adoption of Internet-Based Product Customization and Pricing Strategies" Journal of Management Information Systems, Vol. 17 No. 2 (2000), pp. 9-28.

[21] Dey, D. and Lahiri, A. "Versioning: Go Vertical in a Horizontal Market?", Journal of Management Information Systems, Vol. 33 No. 2 (2016), pp. 546572.

[22] Edelman, B., and Luca, M. "Digital Discrimination: The Case of Airbnb.com." Harvard Business School, Working Paper, No. 14-054, (2014).

[23] Edelman, B., Luca, M., and Svirsky, D. "Racial Discrimination in the Sharing Economy: Evidence from a Field Experiment", (forthcoming) American Economic Journal: Applied Economics.

[24] Eisenhardt, K.M. "Building theories from case study research" Academy of Management Review, Vol. 14, No. 4 (1989), pp. 532-550.

[25] Epstein, R. "How Google Could Rig the 2016 Election - Google has the ability to drive millions of votes to a candidate with no one the wiser, Politico, August 19, 2015, http:/www.politico.com/magazine/story/2015/08/ho W-google-could-rig-the-2016-election-121548.

[26] Epstein, R. And Robertson, R. E. "The search engine manipulation effect (SEME) and its possible impact on the outcomes of elections", Proceedings of the National Academy of Sciences of the United States of America, http://www.pnas.org/content/112/33/E4512.full.

[27] Feldman, N. "Go Ahead and Lie, Donald. You're Protected. Trump's attack on the press doesn't get the First Amendment right.", The New Yorto Tgimg240 
August 15, 2016,

https://www.bloomberg.com/view/articles/2016-0815/go-ahead-and-lie-donald-trump-your-speech-isprotected.

[28] Feldman, N. "Fake News May Not Be Protected Speech -- Is lying on Facebook any better than shouting fire in a crowded theater?" Bloomberg, November 23, 2016, https://www.bloomberg.com/view/articles/2016-1123/fake-news-may-not-be-protected-speech.

[29] Forrester, J. W. Industrial Dynamics, M.I.T. Press, Massachusetts Institute of Technology (1968), pp. 464.

[30] Frank, R.H. and Cook, P. J. The Winner-Take-All Society: Why the Few at the Top Get So Much More Than the Rest of Us, Free Press (1995), pp. 288.

[31] Girotra, K. and Netessine, S. The Risk-Driven Business Model: Four Questions That Will Define Your Company, Harvard Business Review Press (2014), pp. 256.

[32] Grice, A. "Fake news handed Brexiteers the referendum - and now they have no idea what they're doing”, Independent, Wednesday 18 January 2017, available online

http://www.independent.co.uk/voices/michael-goveboris-johnson-brexit-eurosceptic-press-theresa-maya7533806.html.

[33] John, T. "Uber Criticized for Surge Pricing During London Attack", Fortune, Jun 05, 2017, http://fortune.com/2017/06/05/uber-london-attacksurge/.

[34] Kauffman, R. J., and Tsai, J. Y. "The Unified Procurement Strategy for Enterprise Software: A Test of the 'Move to the Middle' Hypothesis", Journal of Management Information Systems, Vol. 26 No. 2 (2009), pp. 177-204.

[35] Kolbert, E. "Why Facts Don't Change Our Minds" - New discoveries about the human mind show the limitations of reason", New Yorker Magazine, February 27,2017 , http://www.newyorker.com/magazine/2017/02/27/w hy-facts-dont-change-our-minds.

[36] Lee, A. S. "A Scientific Methodology For MIS Case Studies," MIS Quarterly Vol. 13, No. 1, (1989), pp. 33-50.

[37] Lee, A. S. "Case Studies as Natural Experiments," Human Relations Vol. 42, No. 2, (1989), pp. 117137.

[38] Levine, H. G. and Rossmoore, D. "Politics and the Function of Power in a Case Study of IT Implementation", Journal of Management Information Systems, Vol. 11, No. 3, (1995) ,pp. 115-134

[39] Levine, H. G. and Rossmoore, D. "Diagnosing the Human Threats to Information Technology Implementation: A Missing Factor in Systems Analysis Illustrated in a Case Study" Journal of Management Information Systems, Vol. 10, No. 2, (1993), pp. 5574.

[40] Malhotra, A., Van Alstyne, M. "The Dark Side of the Sharing Economy . . . and How to Lighten It", Communications of the ACM, Vol. 57 No. 11 (2014), pp. 24-27.
[41] Markopoulos, P. M. and Clemons, E. K. "Reducing Buyers' Uncertainty About Taste-Related Product Attributes", Journal of Management Information Systems, Vol. 30 No. 2 (2013), pp. 269-299.

[42] McCraw, T. K. Prophets of Regulation: Charles Francis Adams - Louis D. Brandeis - James M. Landis - Alfred E. Kahn, Belknap Press (1986), pp. 416.

[43] McFarlan, F. W. "Information Technology Changes the Way You Compete", Harvard Business Review, Vol. 62, No. 3 (1984), pp. 98-103.

[44] Murgia, M. and Kuchler, K. "Facebook struggles to purge fake news", The Financial Times, May 1, 2017, https://www.ft.com/content/0feeafe6-2c0111e7-9ec8-168383da43b7.

[45] PBS NEWSHOUR Extra, "Did fake news influence the outcome of Election 2016?", available online at http://www.pbs.org/newshour/extra/daily_videos/wh $\mathrm{y}$-is-it-important-for-news-sources-to-betrustworthy/.

[46] Piketty, T. Capital in the Twenty First Century, (tr. A. Goldhammer), Belknap Press: An Imprint of Harvard University Press (2014), pp. 704.

[47] Reisinger, D. "Here's How Much Cash You'll Collect From Apple's Price-Fixing Case", Fortune, Jun 21, 2016, http://fortune.com/2016/06/21/applelawsuit-price-fixing/.

[48] Schiller, B. R., First Degree Price Discrimination Using Big Data, Brandies University working Paper Series (2013),

http://www.brandeis.edu/departments/economics/Re PEc/brd/doc/Brandeis WP58.pdf.

[49] Schoemaker, P. "Scenario Planning: A Tool for Strategic Thinking," Sloan Management Review, Vol. 36, No. 2, (1995), pp. 25-40.

[50] Smith, A. "The pedlars of fake news are corroding democracy, The Guardian, 25 November 2016, available online at https://www.theguardian.com/commentisfree/2016/n ov/25/pedlars-fake-news-corroding-democracysocial-networks.

[51] Sterman, J. Business Dynamics: Systems Thinking and Modeling for a Complex World, McGraw-Hill Education (2000), pp. 982.

[52] Warnes, I. “'SICKENING' -- Fury as Uber prices soar after London Bridge terror attack carnage - but firm says it removed 'automatic increase" The Sun, June 4, 2017, https://www.thesun.co.uk/news/3719306/fury-asuber-prices-soar-after-london-bridge-terror-attackcarnage-but-firm-says-it-remove-automaticincrease/.

[53] Wack, P. "Scenarios: Uncharted Waters Ahead," Harvard Business Review, Vol. 63, No. 5, (1985), pp. 72-89.

[54] Wack, P. "Scenarios: Shooting the Rapids," Harvard Business Review, Vol. 63, No. 6. (1985), pp.139-150.

[55] Wu, T. The Master Switch: The Rise and Fall of Information Empires, Knopf (2010), pp. 384. 